УДК 327.7:341.229

DOI: https://doi.org/10.26642/jen-2020-2(92)-101-106

М.О. Псюк, здобувач

Державний університет «Житомирська політехніка»

\title{
Пріоритети державної політики в напрямі розвитку міжнародної кооперації в аерокосмічній галузі
}

\author{
(Представлено: д.держ.упр., проф. О.І. Пархоменко-Куцеввіл)
}

\begin{abstract}
Аерокосмічна галузь на сьогодні є однією з провідних науко- та капіталоємних галузей Украӥни. Визначено, щчо розширення сфери міжнародної кооперації, участь у глобальних науковотехнологічних проєктах, збереження конкурентоздатності на світовому ринку космічних технологій лишаються основними напрямами скеровування зусиль з боку відповідних державних органів управління.

Зазначено, що важливість космічної галузі спонукає національні уряди проводити окрему політику з організаційного забезпечення ї̈ розвитку. В такій політиці особливу роль відіграють інституціональні умови, серед яких визначається пріоритет державної політики в сфері науки, технологій та освіти, зокрема в секторі інтересів космічної діяльності, інтеграчії в глобальну інновачійну сферу, міжнародної кооперації та інтернаціоналізації досліджень, як найважливіший фактор розвитку національної космічної галузі.

Проаналізовано нормативно-правове забезпечення міжнародної діяльності та співпрачі Украйни з державами-партнерами. Співробітництво Украйни з іноземними державами у сфері дослідження та використання космічного простору базується на основоположних міжнародних договорах у иій сфері, міжнародних зобов'язаннях України у сфері космічної діяльності та чинному законодавстві Украӥни, щчо регулює космічну діяльність.

Обтрунтовано необхідність визначення основних пріоритетів державної підтримки розвитку вітчизняної аерокосмічної галузі, які б сприяли поглибленню та розщиренню міжнародних кооперащійних програм та проєктів.

Ключові слова: аерокосмічна галузь; міжнародна кооперація; державна політика.
\end{abstract}

Актуальність теми. Важливою особливістю сучасності є одночасне посилення процесів глобалізації та регіоналізації, зростання взаємозалежності економік різних країн, розвиток інтеграційних процесів, інтенсивний перехід цивілізованих країн від замкнутих національних господарств до економіки відкритого типу.

Важливість розвитку міжнародного кооперування пояснюється, насамперед, сталою тенденцією підвищення науко- та капіталоємності розробки й випуску нової продукції, що вимагає значних фінансових ресурсів. Міжнародна кооперація виробництва дозволяє значно скоротити час налагодження виробництва нових товарів і зменшити їх капіталоємність. Особливо актуальним таке положення є для капіталоємних галузей, до яких належить аерокосмічна галузь. Відтак необхідним постає аналіз можливостей як звичайної, внутрішньої кооперації, так і кооперації міжнародної, іiі необхідності та доцільності для розвитку космічної галузі України. Удосконалення механізму державного управління та надання державної підтримки аерокосмічної галузі, забезпечення інвестиційної привабливості галузі, залучення галузі до процесів міжнародної інтеграції та кооперації дасть змогу створити сприятливі умови для розвитку аерокосмічних компаній України, забезпечити їх доступ до міжнародного ринку космічних послуг і підвищити рівень наукового, виробничого та фінансового потенціалів держави.

Аналіз останніх досліджень та публікації, на які спирається автор. Питанням стратегічного розвитку космічної діяльності України, пріоритетам державної політики в сфері управління аерокосмічною галуззю присвячено публікації В.П. Горбуліна [2], Я.С. Яцківа [10], В.С. Шеховцова, A.I. Шевцова [7], О.В. Дегтярьова [3]. Зокрема, проблеми та завдання організаційно-економічного забезпечення космічної галузі висвітлені в роботах А.А. Возненко [1], І.Дячук [4], С.В. Сіденко [9]. Проте недостатньо досліджено питання організаційних аспектів та державної підтримки космічної діяльності, утворення нових організаційних форм та напрямів розвитку міжнародної кооперації в аерокосмічній галузі України.

Метою статті є обгрунтування пріоритетів державної політики в напрямі розвитку міжнародної кооперації в аерокосмічній галузі.

Викладення основного матеріалу. Космічна галузь України завжди займала одне 3 провідних положень у розробці та виробництві високотехнологічної продукції. На сьогоднішній день галузь потребує активної державної підтримки та удосконалення державного регулювання, реформування організаційних підходів до управління 3 метою вирішення проблем ефективного розвитку галузі. 
Розширення сфери міжнародної кооперації, участь у глобальних науково-технологічних проєктах, збереження конкурентоздатності на світовому ринку космічних технологій лишаються основними напрямами спрямування зусиль з боку відповідних державних органів управління. Можна виокремити такі основні причини, що зумовлюють прагнення провідних світових держав розвивати аерокосмічну галузь незалежно від того, чи може галузь реалізувати за повним замкненим циклом розроблення та експлуатацію космічної техніки:

- ракетно-космічна галузь є каталізатором високих технологій у ключових галузях промисловості, якими визначається рівень розвитку економіки держави, іiі місце на світовому ринку;

- за допомогою ракетно-космічної техніки можна ефективно на світовому рівні вирішувати важливі наукові та народногосподарські завдання зв'язку, радіомовлення, телебачення, космічної індустрії, сільського господарства, меліорації, землекористування, топографії, геологічної розвідки, рибальства, екології, метеорології, навігації тощо;

- рівень розвитку ракетно-космічної техніки значною мірою визначає оборонний потенціал держави. Створення боєздатної і мобільної армії неможливе без використання сучасних космічних засобів i насамперед космічних систем зв'язку, спостереження, розвідки, управління, радіоелектронної боротьби тощо. Загальновизнаним $є$ той факт, що держава, яка володіє ракетно-космічними технологіями, потенційно може мати сучасну зброю;

- ракетно-космічна галузь сама здатна створювати продукцію, яка високо цінується на комерційному ринку космічних послуг [4].

Важливість космічної галузі спонукає національні уряди проводити окрему політику 3 організаційного забезпечення іiі розвитку. В такій політиці особливу роль відіграють інституціональні умови, серед яких визначається пріоритет державної політики в сфері науки, технологій та освіти, зокрема в секторі інтересів космічної діяльності, інтеграції в глобальну інноваційну сферу, міжнародної кооперації та інтернаціоналізації досліджень, як найважливіший фактор розвитку національної космічної галузі.

Україна як активний учасник світової космічної галузі проявляє свою активність у таких напрямах:

участь у міжнародних організаціях, пов'язаних з дослідженням та освоєнням космосу;

участь у міжнародних космічних проєктах;

міждержавна співпраця в космічній галузі [6].

Центральним органом виконавчої влади, що здійснює реалізацію державної політики у сфері космічної діяльності, є Державне космічне агентство України (ДКА). Відповідно до звітних матеріалів, протягом 2018 року ДКА проведено низку заходів міжнародного характеру, спрямованих на просування інтересів України у космічній сфері, у тому числі з метою розширення можливостей виведення продукції та послуг підприємств космічної галузі України на зовнішні ринки, зокрема у межах двосторонніх відносин з іноземними державами та окремими компаніями, а також з міжнародними організаціями [8]. Зокрема, міжнародна діяльність ДКА була спрямована на вирішення таких завдань:

- розвиток співробітництва з іноземними державами;

- виконання заходів у сфері європейської інтеграції України у космічній сфері, розвиток співробітництва з Європейським Союзом та Європейським космічним агентством (ЄКА);

- участь у роботі міжнародних організацій космічної спеціалізації;

- участь у міжнародних виставкових заходах;

- участь у міжнародних режимах нерозповсюдження та експортного контролю та контроль міжнародної діяльності підприємств [8].

Співробітництво України з іноземними державами у сфері дослідження та використання космічного простору в мирних цілях базується на основоположних міжнародних договорах у цій сфері, міжнародних зобов'язаннях України у сфері космічної діяльності та чинному законодавстві України [5], що регулює космічну діяльність.

Політика України у сфері міжнародного співробітництва з іншими країнами визначається такими основними принципами:

- дотриманням міжнародних зобов'язань України в космічній сфері;

- відповідністю пріоритетам і цілям зовнішньої політики України;

- зміцненням позицій українських підприємств на світовому ринку космічної техніки та послуг;

- зосередженням зусиль на пріоритетних напрямах космічної діяльності.

Основні зусилля у сфері міжнародного співробітництва зосереджені на створенні сприятливих міжнародно-правових умов для участі підприємств космічної галузі України в міжнародних космічних проєктах, активізації зовнішньоекономічної діяльності підприємств, їх стабільній активній присутності на ринку космічних послуг. Україна є повноправним суб'єктом міжнародного космічного права, приєднавшись до основоположних актів у сфері дослідження та використання космічного простору, прийнятих в межах $\mathrm{OOH}$. 
Україна є членом міжнародних організацій, які координують космічну діяльність, у тому числі: Комітету $\mathrm{OOH}$ із мирного використання космосу (COPUOS), Всесвітнього комітету із космічних досліджень (COSPAR), Міжагентського комітету з космічного сміття (IADS), Всесвітньої організації 3 супутникових досліджень Землі (CEOS), Міжнародної астронавтичної федерації (IAF).

Підписано двосторонні міжнародні договори щодо співробітництва 3 космічними агентствами $\mathrm{i}$ відомствами Російської Федерації, Казахстану, США, Бразилії, Аргентини, Індії, Китаю, Ізраїлю, Туреччини та країн Європейського Союзу.

Українськими підприємствами космічної галузі встановлено партнерські стосунки 3 провідними світовими аерокосмічними компаніями: «Сi Лонч», «Боїнг», «Локхід Мартін», EADS, «Даза», «ФіатАвіа», РКК «Енергія». Укладено багатосторонні угоди та угоди про співробітництво 3 міжнародними організаціями та телекомунікаційними компаніями «Панамсат», «Інтелсат», «Інтерсупутник», «Свталсат», «Інмарсат», «Свметсат» [6].

Міжнародне співробітництво України в сфері космічної діяльності регулюється двосторонніми нормативно-правовими актами з країнами-партнерам, які встановлюють основні принципи та напрями спільної діяльності. Ця нормативна база $є$ основною для подальшої співпраці та розширення кооперативних зв'язків між країнами та дозволяє українським галузевим компаніям реалізовувати спільні програми та проєкти в межах міжнародної кооперації. На сьогодні Україна співпрацює в аерокосмічній галузі з країнами-партнерами на основі низки двосторонніх угод та галузевих нормативноправових актів, що регулюють конкретні напрями такої співпраці, зокрема:

Азербайджанська Республіка:

- Рамкова угода між Кабінетом Міністрів України та Урядом Азербайджанської Республіки щодо співробітництва у сфері дослідження і використання космічного простору в мирних цілях;

Аргентинська Республіка:

- Рамкова угода між Урядом України та Урядом Аргентинської Республіки про співробітництво у сфері використання космічного простору в мирних цілях;

Алжирська Народна Демократична Республіка:

- Рамкова угода між Урядом України і Урядом Алжирської Народної Демократичної Республіки про співробітництво у сфері дослідження та використання космічного простору в мирних цілях;

Республіка Білорусь:

- Рамкова угода між Кабінетом Міністрів України та Урядом Республіки Білорусь про співробітництво у сфері дослідження і використання космічного простору в мирних цілях;

Федеративна Республіка Бразилія:

- Рамкова угода між Урядом України та Урядом Федеративної Республіки Бразилія про співробітництво у використанні космічного простору в мирних цілях;

- Меморандум між Національним космічним агентством України та Бразильським космічним агентством про співробітництво щодо використання українських ракет-носіїв на пусковому центрі Алкантара;

- Угода між Урядом України та Урядом Федеративної Республіки Бразилія щодо захисту технологій, пов'язаних з участю України в запусках з пускового центру Алкантара;

- Меморандум про взаєморозуміння між Національним космічним агентством України та Бразильським космічним агентством щодо перспективних спільних космічних проєктів;

- Спільна декларація за результатами офіційних переговорів між Президентом України Леонідом Кучмою та Президентом Федеративної Республіки Бразилія Луїзом Інасіо Лулою да Сілва;

- Договір між Україною та Федеративною Республікою Бразилія про довгострокове співробітництво щодо використання ракети-носія «Циклон-4» на пусковому центрі Алкантара;

Арабська Республіка Єгипет:

- Рамкова угода між Урядом України та Урядом Арабської Республіки Єгипет про співробітництво у сфері дослідження та використання космічного простору в мирних цілях;

Європейський Союз:

- Угода про партнерство і співробітництво між Україною і Європейськими Співтовариствами та їх державами-членами;

- Угода між Урядом України та Європейським космічним агентством щодо співробітництва у використанні космічного простору в мирних цілях;

- Угода про співробітництво щодо цивільної глобальної навігаційної супутникової системи (ГНСС) між Свропейським Співтовариством, його державами-членами та Україною;

Держава Ізраїль:

- Угода між Урядом України та Урядом Держави Ізраїль про співробітництво в сфері дослідження та використання космічного простору в мирних цілях;

Республіка Індія: 
- Рамкова угода між Кабінетом Міністрів України і Урядом Республіки Індія про співробітництво у використанні космічного простору в мирних цілях;

Республіка Індонезія:

- Рамкова угода між Кабінетом Міністрів України і Урядом Республіки Індонезія про співробітництво у сфері дослідження та використання космічного простору в мирних цілях;

Республіка Казахстан:

- Угода Урядів Республіки Казахстан і України про принципи співробітництва в галузі забезпечення спільної космічної діяльності;

- Угода про принципи співробітництва Уряду України і Уряду Республіки Казахстан у здійсненні космічної діяльності;

- Угода між Урядом України та Урядом Республіки Казахстан про співробітництво в сфері дослідження та використання космічного простору;

Китайська Народна Республіка:

- Угода між Урядом України і Урядом Китайської Народної Республіки про співробітництво в дослідженні та використанні космічного простору в мирних цілях;

Перу:

- Рамкова угода між Урядом України та Урядом Перу щодо співробітництва у сфері космічної діяльності;

Республіка Корея:

- Угода між Кабінетом Міністрів України та Урядом Республіки Корея щодо співробітництва у використанні космічного простору в мирних цілях;

- Угода між державним космічним агентством України та Міністерством освіти, науки та технологій Республіки Корея про створення Спільного українсько-корейського Комітету з питань співробітництва у використанні космічного простору в мирних цілях;

Російська Федерація:

- Угода між Україною та Російською Федерацією про порядок здійснення гарантійного та авторського нагляду за експлуатацією стратегічних ракетних комплексів Стратегічних Сил, розташованих на їхніх територіях (укр/рос);

- Угода між Урядом України та Урядом Російської Федерації про співробітництво в галузі стандартизації, метрології та сертифікації;

- Протокол між Міністерством оборони України і Міністерством оборони Російської Федерації про наміри в сфері військового і військово-технічного співробітництва в галузі космічної діяльності;

- Угода між Урядом України і Урядом Російської Федерації про співробітництво в галузі створення та експлуатації ракетно-космічної та ракетної техніки;

- Угода між Національним космічним агентством України і Російським космічним агентством 3 питань комерційного використання РН «Зеніт»;

- Угода між Урядом України і Урядом Російської Федерації про співробітництво в сфері дослідження і використання космічного простору в мирних цілях;

- Угода між Урядом України та Урядом Російської Федерації про засоби систем попередження про ракетний напад і контролю космічного простору (укр/рос);

- Спільна заява Президентів України та Російської Федерації, підписана 31 травня 1997 р. у м. Києві;

- Угода про порядок застосування ексклюзивного права компанії «Сі Лонч Лімітед Партнершип»на використання ракети-носія «Зеніт» при проведенні комерційних пусків 3 космодрому «Байконур»;

- Угода між Національним космічним агентством України, Російським космічним агентством, Національною академією наук України і Російською академією наук про створення Міжнародного центру космічного права;

- Угода між Національним космічним агентством України та Міністерством оборони Російської Федерації про співробітництво в галузі спеціального контролю;

- Угода між Кабінетом Міністрів України та Урядом Російської Федерації про переміщення товарів у рамках співробітництва в освоєнні космічного простору, створенні та експлуатації ракетно-космічної та ракетної техніки (укр/рос);

- Меморандум про взаємодію Російського авіаційно-космічного агентства i Національного космічного агентства України при проведенні робіт зі стандартизації ракетно-космічної техніки;

- Меморандум про співробітництво між Національним космічним агентством України і Російським авіаційно-космічним агентством в галузі розвитку глобальних навігаційних супутникових систем;

- Угода між Кабінетом Міністрів України та Урядом Російської Федерації щодо заходів з охорони технологій у зв'язку зі співробітництвом у сфері дослідження і використання космічного простору в мирних цілях і в створенні та експлуатації ракетно-космічної і ракетної техніки (укр/рос);

- Протокол между Правительством Российской Федерации и Кабинетом Министров Украины о внесении изменений в Соглашение между правительством Российской Федерации и Правительством 
Украины о сотрудничестве в области исследования и использования космического пространства в мирных целях;

- Угода між Кабінетом Міністрів України та Урядом Російської Федерації про співробітництво в галузі використання та розвитку російської глобальної навігаційної супутникової системи ГЛОНАСС;

- Меморандум про взаєморозуміння між Державним космічним агентством України та Федеральним космічним агентством (Російська Федерація) щодо співробітництва у використанні національних космічних засобів дистанційного зондування Землі цивільного призначення;

- Меморандум про взаєморозуміння між Державним космічним агентством України та Федеральним космічним агентством (Російська Федерація) стосовно співробітництва у сфері ракетно-космічної промисловості;

Королівство Саудівська Аравія:

- Угода між Урядом України та Урядом Королівства Саудівська Аравія про співробітництво у сфері дослідження та використання космічного простору в мирних цілях;

Республіка Судан:

- Угода між Урядом України та Урядом Республіки Судан про співробітництво у сфері дослідження та використання космічного простору в мирних цілях;

Сполучені Штати Америки:

- Угода між Україною і Сполученими Штатами Америки щодо надання допомоги Україні в ліквідації стратегічної ядерної зброї, а також запобігання розповсюдженню зброї масового знищення;

- Угода між Урядом України та Урядом Сполучених Штатів Америки про захист технологій, пов’язаних із запуском Україною ліцензованих США комерційних космічних апаратів;

- Рамкова угода між Урядом України та Урядом Сполучених Штатів Америки про співробітництво в дослідженні та використанні космічного простору в мирних цілях;

Турецька Республіка:

- Угода між Урядом України та Урядом Турецької Республіки про співробітництво в сфері дослідження та використання космічного простору.

Космічна галузь України співпрацює 3208 компаніями й організаціями різних регіонів світу: в американському регіоні - із 44 компаніями, європейському - 56, азіатсько-тихоокеанському - 34, у країнах Близького Сходу та Африки - 74 компаніями [7, 9]. На сьогоднішній день рівень розвитку космічної галузі України дозволяє провадити різноманітні наукові та комерційні проекти. Натомість перед Україною постає проблема закритості, привілейованості міжнародних ринків космічної продукції.

Для виходу на міжнародні ринки українським підприємствам необхідно віднаходити нові шляхи та нові можливості. Однак специфічність національних та міжнародного ринків аерокосмічної продукції та послуг значно ускладнює вирішення таких завдань. Сьогодні в Україні не існує повноцінного попиту та ринку збуту для технологій та продукції підприємств вітчизняної космічної галузі. Відтак, неминучою $є$ необхідність побудови ефективної політики та пошуку ринків збуту за межами держави, а також визначення основних пріоритетів державної підтримки розвитку вітчизняної аерокосмічної галузі, які б сприяли поглибленню та розширенню міжнародних коопераційних програм та проектів.

Висновки та перспективи подальших досліджень. Система державного управління аерокосмічною галуззю України потребує подальшого вдосконалення в напрямі розвитку організаційних підходів до управління та забезпечення можливостей українським компаніям, що працюють у галузі, для широкої міжнародної кооперації.

Подальший розвиток міждержавної співпраці, розширення кола країн-партнерів на державному рівні сприятиме росту міжнародних програм та проєктів з участю вітчизняних компаній, забезпечить повноцінну інтеграцію української аерокосмічної галузі у світовий науково-технологічний та економічний простір.

\section{Список використаної літератури:}

1. Возненко А.А. Оцінка ефективності державної допомоги космічній галузі / А.А. Возненко // Наукові праці НДФІ. - 2019. - № 1 (86). - С. 118-130.

2. Горбулін В.П. Космічна галузь України: пріоритетні напрями діяльності в нових умовах / В.П. Горбулін // Стратегічні пріоритети. - 2016. - № 1 (38). - С. 5-12.

3. Дегтярев А.В. Основные тенденции и перспективы развития мировой космической деятельности / А.В. Дегтярев, В.С. Шеховцов // Космическая техника. Ракетное вооружение : сб. науч. ст. Днепропетровск, 2010. - № 3. - С. 3-11.

4. Дячук І.Д. Космічний потенціал в системі національних цінностей держави / I.Д. Дячук // Наука та наукознавство. Додаток. Матеріали VII Добровської конференції. - 2007. - № 4. - С. 43-50.

5. Закон України «Про космічну діяльність» № 502/96-ВР від 15.11.1996 р. [Електронний ресурс]. - Режим доступу : https://zakon.rada.gov.ua/laws/show/502/96-\%D0\%B2\%D1\%80\#Text.

6. Міжнародна діяльність / Сайт Державного космічного агентства України [Електронний ресурс]. - Режим доступу : https://www.nkau.gov.ua/ua/activity/mizhnarodna-diialnist. 
7. Шевцов А.І. Основні тенденції розвитку світової космічної діяльності: перспективи України / А.I. Шевцов, В.С. Шеховияов // Стратегічна панорама. - 2004. - № 4. - С. 85-94.

8. Річний звіт Державного космічного агентства України за 2018 рік [Електронний ресурс]. - Режим доступу : https://www.nkau.gov.ua/docs/vydannya/Annual_report_SSAU_2018.pdf.

9. Сіденко С.В. Науково-виробнича кооперація України в аерокосмічній галузі / C.B. Сіденко // Актуальні проблеми міжнародних відносин. - 2012. - № 110 (Ч. 1). - С. 47-50.

10. Яиків Я.С. Космос - не примха, а наше майбутнє / Я.С. Яиків // Space Ukraine [Електронний ресурс]. Режим доступу : http://spaceukraine.com/ua/2017/10/04/yaroslav-yatskiv-space-is-not-a-fantasy-its-our-future/.

\section{References:}

1. Voznenko, A.A. (2019), «Ocinka efektyvnosti derzhavnoi' dopomogy kosmichnij galuzi»,Naukovi pratsi NDFI, No. 1 (86), pp. 118-130.

2. Gorbulin, V.P. (2016), «Kosmichna galuz' Ukrai'ny: priorytetni naprjamy dijal'nosti v novyh umovah», Strategichni priorytety, No. 1 (38), pp. 5-12.

3. Degtyarev, A.V. and Shekhovtsov, V.S. (2010), «Osnovnye tendentsii i perspektivy razvitiya mirovoi kosmicheskoi deyatel'nosti», Kosmicheskaya tekhnika. Raketnoe vooruzhenie, sb. nauch. st., Dnepropetrovsk, No. 3, pp. 3-11.

4. Djachuk, I.D. (2007), «Kosmichnyj potencial v systemi nacional'nyh cinnostej derzhavy», Nauka ta naukoznavstvo, Dodatok. Materialy VII Dobrovs'koi' konferencii', No. 4, pp. 43-50.

5. VRU (1996), Zakon Ukrai'ny «Pro kosmichnu dijal'nist'», No. 502/96-VR vid 15.11.1996 r., [Online], available at: https://zakon.rada.gov.ua/laws/show/502/96-\%D0\%B2\%D1\%80\#Text

6. DKA, «Mizhnarodna dijal'nist'», Sajt Derzhavnogo kosmichnogo agentstva Ukrai'ny, [Online], available at: https://www.nkau.gov.ua/ua/activity/mizhnarodna-diialnist

7. Shevcov, A.I. and Shehovcov, V.S. (2004), «Osnovni tendencii' rozvytku svitovoi' kosmichnoi' dijal'nosti: perspektyvy Ukrai'ny», Strategichna panorama, No. 4, pp. 85-94.

8. Richnyj zvit Derzhavnogo kosmichnogo agentstva Ukrai'ny za 2018 rik, [Online], available at: https://www.nkau.gov.ua/docs/vydannya/Annual_report_SSAU_2018.pdf

9. Sidenko, S.V. (2012), «Naukovo-vyrobnycha kooperacija Ukrai'ny v aerokosmichnij galuzi», Aktual'ni problemy mizhnarodnyh vidnosyn, No. 110 (Ch. 1), pp. 47-50.

10. Jackiv, Ja.S., «Kosmos - ne prymha, a nashe majbutnje», Space Ukraine, [Online], available at: http://spaceukraine.com/ua/2017/10/04/yaroslav-yatskiv-space-is-not-a-fantasy-its-our-future/

Псюк Михайло Олександрович - здобувач Державного університету «Житомирська політехніка». Наукові інтереси:

- державне управління;

- державне регулювання космічної галузі.

http://orcid.org/0000-0003-3786-7081. 